\title{
CHANGES IN THE YIELD AND BIOCHEMICAL COMPOSITION OF THE FRUIT OF OKRA (HIBISCUS ESCULENTUS L.) WHEN PLANTING AT DIFFERENT TIMES IN THE CONDITIONS OF TASHKENT REGION
}

\author{
Ibrokhimov Bakhodir Akmal ugli ${ }^{1}$ and Nizomov Rustam Akhrolovich ${ }^{2}$ \\ ${ }^{1}$ Doctoral student (PhD), Research Institute of Vegetables, Melon Crops and Potato Growing, \\ McMahons Road, Frankston 3199, Australia111106, Kuksaroy str. 3, Tashkent Region, Uzbekistan. \\ ${ }^{1}$ Doctor of Agricultural Sciences, Senior Researcher, Research Institute of Vegetables, Melon Crops and Potato \\ Growing, McMahons Road, Frankston 3199, Australia111106, Kuksaroy str. 3, Tashkent Region, Uzbekistan.
}

https://doi.org/10.35410/IJAEB.2020.5564

\begin{abstract}
In recent years, scientific research work have been conducted by leading research institutions to study and introduce new and unconventional promising vegetables and to select species and varieties that are resistant to certain soil and climatic conditions. Okra (Hibiscus esculentus L.), which belongs to the family of Malvaceae, is one of such promising vegetables. The article describes the changes in the yield of okra (Hibiscus esculentus L.) at different planting times, i.e. on April 1, 10, 20, 30 and May 10, and the biochemical content of protein, fat, carbohydrates, water, macro and micro elements in the content of 100 gisemol-bearing fruit.
\end{abstract}

Keywords: Okra, planting scheme, planting time, variety, fruit, maturation, biologic full maturation, number of fruits, weight of fruits.

\section{INTRODUCTION}

It is necessary to further develop scientific research and introduce scientific achievements into the production in order to use irrigated lands efficiently, obtain abundant and high-quality yield, and increase livestock productivity to a high level. In recent years, leading research institutions have been conducting research to study and introduce new and unconventional promising vegetables and to select species and varieties that are resistant to certain soil and climatic conditions. Okra (Hibiscus esculentus L.), which belongs to the family of Malvaceae, is one of such promising vegetables.

Growth, development and productivity of some specimens in the collection of okra in the conditions of Tashkent region were investigated by S.S. Berlyand [1, 2], I.I. Pugachev, L.G. Kalyagina [3], V.I. Zuev, O. Kadirkhodjaev [4], B.Yo. Tukhtaev [5], N.K. Safarova [2] conducted experiments to study the water regime of okra in Tashkent and Khorezm regions. The authors recommended the use of 3 specimens with early and middle ripening, smoothgrained, rich in ascorbic acid in the selection process [3].

The morphological, biological and farm traits of okra as a vegetable crop, and the technology of its cultivation have not been fully studied in Uzbekistan yet. 
In many English-speaking countries, okra is called a lady's fingers, ochro or gumbo, in Portuguese quabo, French gumbo, in India bhe or bhendi [7]. Okra (Hibiscus esculentus L.) is a perennial plant (cultivated annual plant) belonging to the Hibiscus group of the family Malvaceae, grown in all tropical countries - Asia, Africa, America and Southern Europe. Besides its homeland - tropical Africa, okra is one of the most common vegetables in other countries too. It is known from historical sources that okra was cultivated in ancient Egypt as early as two thousand years BC. In the flora of Uzbekistan there are 27 species of the family Malvaceae belonging to 7 genera [8]. Okra is used in several ways in terms of nutritional, economical and industrial purposes. Edible okra fruits contain carbohydrates, protein, fat, iron, calcium, fiber, thiamine, nicotinamide, riboflavin and ascorbic acid. $100 \mathrm{~g}$ of mature okra seeds contain up to $20 \%$ fat and 20,23\% crude lysine, a high content of protein and vitamin C [9].

\section{MATERIALS AND METHODS}

The experiments were conducted in the experimental fields of the Research Institute of Vegetables, Melon crops and Potato growing in 2018-2020. The institute is located in north of Tashkent city, in the district Tashkent of Tashkent region.

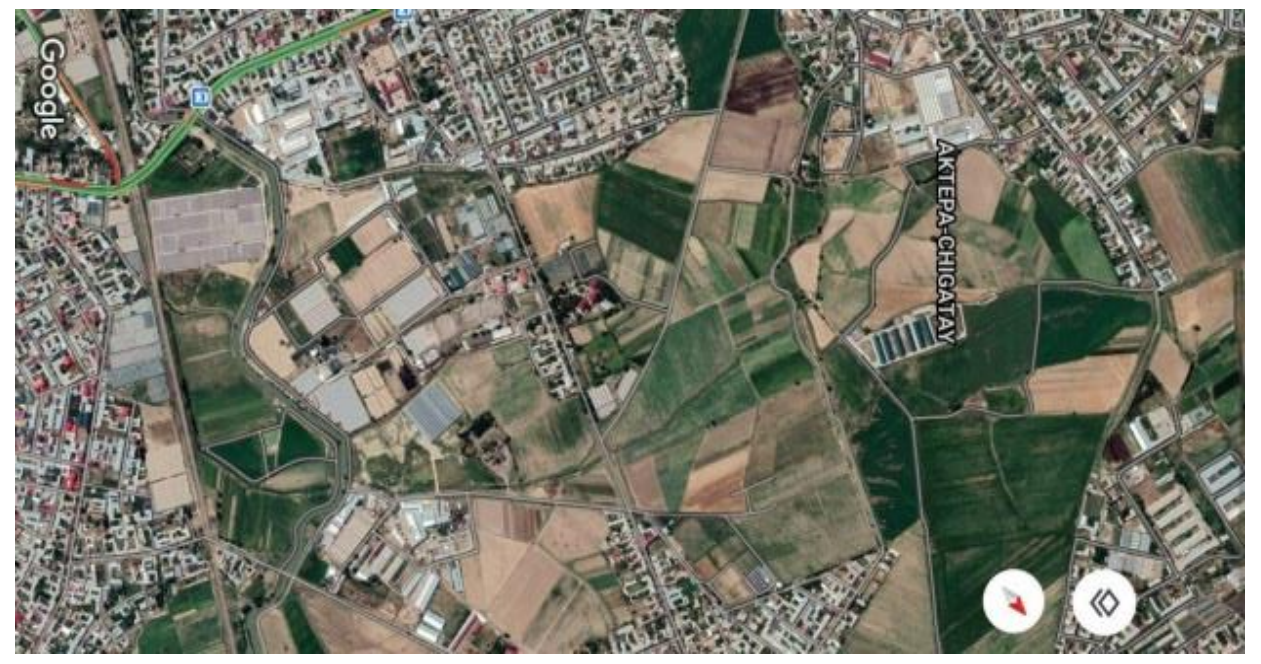

The object of research was the varieties of okra - "Tashkent tuhfasi" and "Burgundy", their fruits, seeds and leaves. Field experiments were carried out on the basis of methodological manuals "Methods of conducting experiments in vegetable, melon and potato growing" [10].

\section{RESULTS AND DISCUSSION}

Sowing dates should be determined on the basis of soil and climatic conditions of the region, the method of cultivation, as well as the biological characteristics of the plant considering the results of experiments. Both, the very early planting of seedlings, and the delay in planting dates also affect the growth and yield of plants.

With the above in mind, research has been conducted to determine the most favorable spring planting dates for okra. 
In the study, okra seedlings were tested in 5 planting dates: 1, 10, 20, 30 April and the 10th of May by planting seedlings in the open field.

The average weight of fruits in the control variant of the "Tashkent tuhfasi" variety of okra planted at different planting times, was $16,0 \mathrm{~g}$. Fruit weight was $19,2 \mathrm{~g}$ or $120,0 \%$ compared to the control variant in the first period, while in the control period in the rest planting periods it was $95,6-101,9 \%$, there was no big difference. In "Burgundy" variety, the average weight of fruit per plant was $21 \mathrm{~g}$ in the seedlings planted on April 20 control period, while the seedlings planted on April 10 and May 10 produced slightly less fruits of 20,3-19,3 g than the control period, in the seedlings planted on April 1 and 30, the fruit weight weighed more 22,1-21,3g than the control period.

The weight of fruits per plant was $0,273 \mathrm{~kg}$ in "Tashkent tuhfasi" variety, while in seedlings planted only on April 30, it was 0,294 kg higher than the control period. We can observe that the seedlings planted in the remaining periods April 1, April 10, and May 10, the indications were $84,6-98,7 \%$ lower than the control period. In "Burgundy" variety, in the seedlings planted only on April 30the weight of the fruit on a single plant yielded higher than the control. In our experiments, it was proved that the seedlings planted in the remaining periods yielded less than the control.

The average yield per hectare was 13 tons in the control period of "Tashkent tuhfasi" variety, while in the seedlings planted on April 1, this indication was 11 tons, in the seedlings planted on April 10, it was 11,5 tons, and in the seedlings planted only on April 30, the yield was 1 ton more than control planting period, that is 14 tons. In the seedlings planted on May 10, it was 11,7 tons, which is 1,3 tons less than the control period.

The average yield per hectare in "Burgundy" variety was 10 tons in the control planting period. We can observe that the average yield of seedlings planted during the experimental planting period was 1,2 tons higher in "Burgundy" variety than the control period in the seedlings planted on April 30 as it was noted in "Tashkent tuhfasi" variety, and in the remaining periods the yield was $0,3-0,8$ tons less compared to the control.

Marketable productivity. In both experiments, we can observe that the higher the yield is, the higher marketable product is in both varieties of okra in the experiment (Table 1).

The biochemical composition of fruits is also very important, so the significance of protein, fat, carbohydrates, water, macro and micro elements in in the content $100 \mathrm{~g}$ of edible product, fruit were studied at different planting times (Table 2).

Table 1: Marketable fruit weight and number of fruits per plant in okra varieties planted according to different sowing schemes (2019)

\begin{tabular}{|c|c|c|c|c|c|c|c|c|}
\hline \multirow{3}{*}{ Planting dates } & \multicolumn{6}{|c|}{ In one plant at maturation period of fruits } \\
\cline { 2 - 9 } & \multicolumn{2}{|c|}{$\begin{array}{c}\text { Mean weight of a } \\
\text { fruit }\end{array}$} & \multicolumn{2}{|c|}{ Weight of all fruit } & \multicolumn{2}{|c|}{ Yield } & \multicolumn{2}{c|}{ Marketable yield } \\
\cline { 2 - 9 } & $\mathrm{g}$ & $\%$ & $\mathrm{~kg}$ & $\%$ & $\mathrm{t} / \mathrm{ha}$ & $\%$ & $\mathrm{t} / \mathrm{ha}$ & $\%$ \\
\hline
\end{tabular}


International Journal of Agriculture, Environment and Bioresearch

Vol. 5, No. 05; 2020

ISSN: $2456-8643$

\begin{tabular}{|c|c|c|c|c|c|c|c|c|}
\hline \multicolumn{7}{|c|}{ "Tashkent tuhfasi" variety } \\
\hline April 1 & 19,2 & 120,0 & 0,231 & 84,6 & 11,0 & 84,6 & 10,7 & 86,3 \\
\hline April 10 & 16,1 & 100,6 & 0,241 & 88,3 & 11,5 & 88,5 & 11,2 & 90,3 \\
\hline April 20 (control) & 16,0 & 100,0 & 0,273 & 100,0 & 13,0 & 100,0 & 12,4 & 100,0 \\
\hline April 30 & 16,3 & 101,9 & 0,294 & 107,7 & 14,0 & 107,7 & 13,9 & 112,1 \\
\hline May 10 & 15,3 & 95,6 & 0,245 & 89,7 & 11,7 & 90,0 & 11,1 & 89,5 \\
\hline Average & 16,6 & 104,0 & 0,256 & 93,8 & 12,2 & 93,8 & 11,9 & 95,7 \\
\hline \multicolumn{7}{|c|}{ "Burgundy” variety } \\
\hline April 1 & 22,1 & 105,2 & 0,195 & 92,9 & 9,5 & 95,0 & 9,0 & 94,7 \\
\hline April 10 & 20,3 & 96,7 & 0,203 & 96,7 & 9,7 & 97,0 & 9,4 & 98,9 \\
\hline April 20 (control) & 21,0 & 100,0 & 0,210 & 100,0 & 10,0 & 100,0 & 9,5 & 100,0 \\
\hline April 30 & 21,3 & 101,4 & 0,235 & 111,9 & 11,2 & 112,0 & 11,0 & 115,8 \\
\hline May 10 & 19,3 & 91,9 & 0,193 & 91,9 & 9,2 & 92,0 & 8,9 & 93,7 \\
\hline Average & 20,8 & 99,0 & 0,207 & 98,6 & 9,9 & 99,0 & 9,6 & 101,0 \\
\hline
\end{tabular}

Table 2: Biochemical composition of okra fruit planted at different planting times (2019)

\begin{tabular}{|c|c|c|c|c|c|c|c|c|c|c|c|c|}
\hline \multirow{3}{*}{$\begin{array}{c}\text { Planting } \\
\text { dates }\end{array}$} & \multicolumn{12}{|c|}{ Nutrients in $100 \mathrm{~g}$ edible product } \\
\hline & \multicolumn{2}{|c|}{ protein } & \multicolumn{2}{|c|}{ fat } & \multicolumn{2}{|c|}{ carbohydrates } & \multicolumn{2}{|c|}{ water } & \multicolumn{2}{|c|}{$\begin{array}{l}\text { Macro- } \\
\text { elements }\end{array}$} & \multicolumn{2}{|c|}{$\begin{array}{l}\text { Micro- } \\
\text { elements }\end{array}$} \\
\hline & $\mathbf{g}$ & $\%$ & $\mathbf{g}$ & $\%$ & $\mathbf{g}$ & $\%$ & $\mathbf{g}$ & $\%$ & mg & $\%$ & $\mathrm{mg}$ & $\%$ \\
\hline \multicolumn{13}{|c|}{ "Tashkent tuhfasi" variety } \\
\hline April 1 & 1,7 & 85,0 & 0,3 & 150,0 & 7,8 & 92,9 & 88,7 & 99,6 & 504 & 99,8 & 111 & 97,4 \\
\hline April 10 & 2,2 & 110,0 & 0,2 & 100,0 & 8,8 & 104,8 & 88,2 & 99,0 & 508 & 100,6 & 110 & 96,5 \\
\hline $\begin{array}{l}\text { April 20 } \\
\text { (control) }\end{array}$ & 2 & 100,0 & 0,2 & 100,0 & 8,4 & 100,0 & 89,1 & 100,0 & 505 & 100,0 & 114 & 100,0 \\
\hline April 30 & 2,2 & 110,0 & 0,3 & 150,0 & 7,8 & 92,9 & 87,5 & 98,2 & 504 & 99,8 & 113 & 99,1 \\
\hline May 10 & 2,1 & 105,0 & 0,2 & 100,0 & 7,6 & 90,5 & 88,3 & 99,1 & 503 & 99,6 & 111 & 97,4 \\
\hline \multicolumn{13}{|c|}{ "Burgundy" variety } \\
\hline April 1 & 2,2 & 100,0 & 0,2 & 100,0 & 7,9 & 96,3 & 89,1 & 100,0 & 502 & 100,2 & 111 & 98,2 \\
\hline April 10 & 2,3 & 104,5 & 0,2 & 100,0 & 8,3 & 101,2 & 88,2 & 99,0 & 503 & 100,4 & 112 & 99,1 \\
\hline $\begin{array}{l}\text { April 20 } \\
\text { (control) }\end{array}$ & 2,2 & 100,0 & 0,2 & 100,0 & 8,2 & 100,0 & 89,1 & 100,0 & 501 & 100,0 & 113 & 100,0 \\
\hline April 30 & 2,3 & 104,5 & 0,2 & 100,0 & 8,5 & 103,7 & 87,4 & 98,1 & 503 & 100,4 & 114 & 100,9 \\
\hline May 10 & 2,1 & 95,5 & 0,2 & 100,0 & 8,1 & 98,8 & 87,4 & 98,1 & 501 & 100,0 & 112 & 99,1 \\
\hline
\end{tabular}

The highest rate of protein was observed in "Tashkent tuhfasi" variety planted on April 20 and 30 compared to control planting period April 20, which is 10\% higher than the control period. The lowest indication was noted in the seedlings planted on April 1, 15\% lower than in the control planting period. possible. In "Burgundy" variety, this indication was 2,7-4,5\% higher in sowing periods April 1, April 10, and April 30 than the control period, only in sowing period May 10, it was $0,1 \mathrm{~g}$ less. 
During the planting period of April 1 and April 30, the fat in $100 \mathrm{~g}$ edible product was 0,1 grams more in "Tashkent tuhfasi" variety than in the control period. While in "Burgundy" variety, the fat content remained unchanged during all planting periods.

Carbohydrates in the seedlings of "Tashkent tuhfasi" variety planted on April 10 were 0,2 grams more compared to the control sowing period, and 0,6-0,8 grams less in the fruits of the seedlings planted on April 1, April 30 and May 10 than in the control one. In "Burgundy" variety, carbohydrates were the highest during the April 10 sowing period, which was 3,7\% higher than the control sowing period. On planting period April 10, it was slightly higher at 8,3 grams. It was observed that in the remaining planting periods April 1 and May 10, this indication was 1,2-3,7\% lower than the control period.

Whether it is a living thing or a plant, its source of life is water. The main part of the composition of okra fruits is water, we learned in the course of our experiments that the water content of okra fruits is $87,4-91,1 \%$. It was observed that in "Tashkent tuhfasi" variety during the sowing periods studied in our experiment, the water content was 0,4-1,6 grams less than in the control period. In "Burgundy" variety, the water in fruit content of seedlings planted on April 10, April 30 and May 10 was 1,1-2,7 grams less than the control period, and the seedlings planted on April 1 collected the same amount of water as in the control period.

Macroelements in "Tashkent tuhfasi" variety planted in the sowing period on April 10 can be observed to be $0,6 \%$ higher than in the control period and in the remaining sowing periods on April 1, April 30 and May 10, it was 0,2-0,4\% less than the control period. In "Burgundy" variety, it was found that in all the planting periods of our experiment, it was $0,02-0,04 \%$ higher than the control period.

It was found that microelements in "Tashkent tuhfasi" variety were 1-4 mg less at all sowing periods than in the control period. While in "Burgundy" variety, the microelements in the fruit of seedlings planted during April 30 were found to be $1 \mathrm{mg}$ higher than the control period. As can be seen in Table 2, in the sowing periods April 1, April 10, and May 10, they were 1-2 mg less than the control period.

\section{CONCLUSIONS}

The yield of okra in the variety "Tashkent tuhfasi" was $13 \mathrm{t} / \mathrm{ha}$ when sown at the control sowing period April 20 and 14 t/ha during the sowing period April 30. In "Burundy" variety, the yield was $1,2 \mathrm{t} / \mathrm{ha}$ higher when sown at the sowing period April 30 than in the control variant.

Nutrients in $100 \mathrm{~g}$ of okra fruit were found to be partially high for the planting period April 30, although no significant change in the control was observed.

\section{REFERENCES}

[1]S.S. Berlyand. Towards agrobiological study of okra. Bass culture. Moscow: Selhozgiz, pp.376-397, 1950. (in Russian)

[2]S.S. Berlyand. Towards the study of the varieties of okra (Hibiscus esculentus L.). Trudi VIR. T.23. edition. 1-4., Moscow-Leningrad, pp. 301-318, 1930. (in Russ.) 
[3]I.I. Pugachev, L.G. Kalyagina. Study of the collection of okra in the conditions of Uzbekistan. The use of world collections for the selection of vegetable and fruit crops in Uzbekistan. Tashkent: SAFVNIIR SAO VASHNIL, pp. 4-8, 1987. (in Russ.)

[4]V. Zuev, O. Kodirkhodjaev. Okra. Uzbekistan agriculture. Tashkent, № 6. pp. 19-20, 2003. (in Russ.).

[5]Tukhtaev B.Yo. Introduction of medicinal plants to saline lands of Uzbekistan. Abstract of diss. doc. bio. sci. -Tashkent,

p. 38, 2009. (in Russ.)

[6]N.K. Safarova. Biology and water regime of Hibiscus esculentus L. at different introduction conditions. Abstract of diss. PhD. biol. sci. -Tashkent, pp. 22-26, 2010. (in Uzbek)

[7]D. Obeng-Ofori, E. Yirenkyi-Danquah, J. Ofosu-Anim. Vegetable and spice crop production in West Africa. Accra, Ghana: Sam Wood Ltd. 68-70, 2007.

[8]S.N. Kudryashev. Family Malvaceae (except the genus Gossypium and decorative species of Hibiscus). In Flora of Uzbekistan. T. IV. -Tashkent: Publ. AS USSR, pp. 162-183, 1959.

[9]A.A. Fajinmi, O.B. Fajinmi. Incidence of okra mosaic virus at different growth stages of okra plants (Abelmoschus esculentus (L.) Moench) under tropical condition. Journal of General and Molecular Virology, No 2, pp. 28-31, 2010.

[10]B.J. Azimov, B.B. Azimov. Methodological manuals "Methodics of conducting experiments in vegetable, melon crops and potato growing". Tashkent, 2002. 